\title{
Management techniques of maize crop in the marginal growing area in Finland
}

\author{
Seppo Pulli
}

University of Helsinki, Dept. of Plant Husbandry, 00710 Helsinki 71

Osmo KARA

University of Helsinki, Dept. of Farm Engineering, 00710 Helsinki 71

P. M. A. Tigerstedt

University of Helsinki, Dept. of Plant Breeding, 00710 Helsinki 71

G. BRÜNINGHAUS

Wiurila, 24910 Halikko

\begin{abstract}
Silage maize management studies were carried out in $1976-78$ on the University farm in Siuntio in southern Finland. Seeding time trials in 1976-77 consisted of three different types of varieties seeded at four different times between May 11 and June 8. In 1978 three seeding dates were tested in relation to the seeding depth of the maize. Population density studies were carried out in 1976-77.

As a result of the management studies it can be concluded that the weather conditions were so unfavorable that true differences could not be found because even the best alternative in the management technique did not give a satisfactory agronomic result. Seeding dates from May 15 to May 25 can be recommended. Relatively heavy frosts in early June $\left(-4^{\circ} \mathrm{C}\right.$ to $\left.-6^{\circ} \mathrm{C}\right)$ will hurt stands but they do not kill the plant. The advance earned with early planting is thus not totally lost through the frosts

Seeding depths of 5 to $7 \mathrm{~cm}$ are recommended. Population densities more than 10 plants $/ \mathrm{m}^{2}$ are not necessary for the maximum yield. In average or better than average growing conditions the planting densities of 6 to 8 plants $/ \mathrm{m}^{2}$ could yield a more mature forage crop.
\end{abstract}

\section{ntroduction}

With the open pollinated varieties as used in the 1930's the recommended seeding dates were at the beginning of June (Virtanen 1940). According to VIRTANEN's studies the recommended seeding rate was $120 \mathrm{~kg} / \mathrm{ha}$ (35 plants/ $\mathrm{m}^{2}$ ) with a row distance of $40 \mathrm{~cm}$ and with a seeding depth of $7-8 \mathrm{~cm}$. In the seeding date trials at Tammisto Plant Breeding Station Ravantri (1960), the highest dry matter yields were obtained with seeding dates between May 20 and June 4 during the test years 1953-58. In Tikkurila YLlö (1962) rec- 
ommended seeding dates from late May to early June. Seeding date should be adjusted to the soil temperature, which should be around 8 to $10^{\circ} \mathrm{C}$ at the depth of the seed placement. YLLÖ recommended a seeding rate of $100 \mathrm{~kg} / \mathrm{ha}$ with a row distance of 40 to $50 \mathrm{~cm}$ and with a seeding depth of 7 to $8 \mathrm{~cm}$. The recommendations of YLLÖ are similar to those of GELIN and Gustafsson (1959), Åberg and LARsson (1959) and LARsson (1959) obtained in Sweden. The important point is that the plant densities in the 1930's, 1940's and 1950's were much higher than those experienced today in Europe and America.

Because of the very favorable breeding development of high yielding hybrids and the emphasis on silage quality instead of total biomass, the recommended crop densities today are only $25-30 \%$ of those recommended earlier. In the USA the recommended silage maize population densities are 6 plants $/ \mathrm{m}^{2}$ which makes a seeding rate of $20-22 \mathrm{~kg} /$ ha (MARTIN et al. 1975). In the studies of NösBERGER (1971) in Zürich the total dry matter yield increased with increasing plant densities up to 14 plants $/ \mathrm{m}^{2}$. The grain yield reached the peak with 12 plants $/ \mathrm{m}^{2}$. In Great Britain the recommended seeding rates for grain yield and for silage stand are 10 and 13 plants $/ \mathrm{m}^{2}$ (ANoN. 1974).

The management studies of maize conducted in 1976 consisted of seeding time trials, seeding depth studies and population density experiments related to the varieties best adapted to growing conditions in Finland.

\section{Materials and methods}

Silage maize trials with different management studies were carried out at the University farm in Siuntio in 1976-78. The research program consisted of the following types of experiments:

A. Seeding dates and varieties in $1976-77$

\begin{tabular}{|c|c|}
\hline 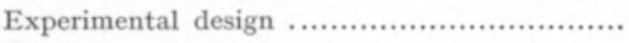 & Split-plot \\
\hline 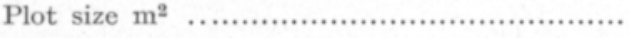 & 48 \\
\hline 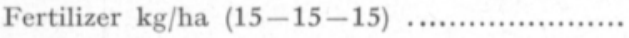 & 1000 \\
\hline 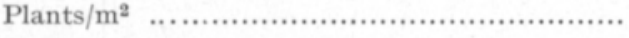 & 10 \\
\hline 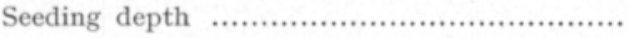 & 7 \\
\hline Row distance $\mathrm{cm}$........... & 80 \\
\hline
\end{tabular}

Treatments:

Seeding dates I

,$\quad$ II

,$\quad$ III

, IV

(n)

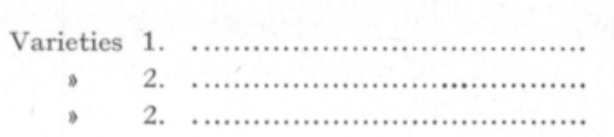

Main plot

$\begin{array}{cr}\text { May } & 14 \\ 3 & 21 \\ \text { June } & 2 \\ & 8\end{array}$

$\begin{array}{cc}\text { May } & 11 \\ -\quad 20 \\ -\quad 27 \\ \text { June } \quad 3\end{array}$

Sub-plot

Flash

Flash

LG 5

LG 11

ACG 200 
Experimental design

Rand. block

48

1000

May 14

7

80

LG 5

Population densities

$\begin{array}{rr}70000 / \text { ha } & 70000 / \text { ha } \\ 100000 & 100000 \\ 130000 & 130000\end{array}$

C. Seeding dates and depths in 1978

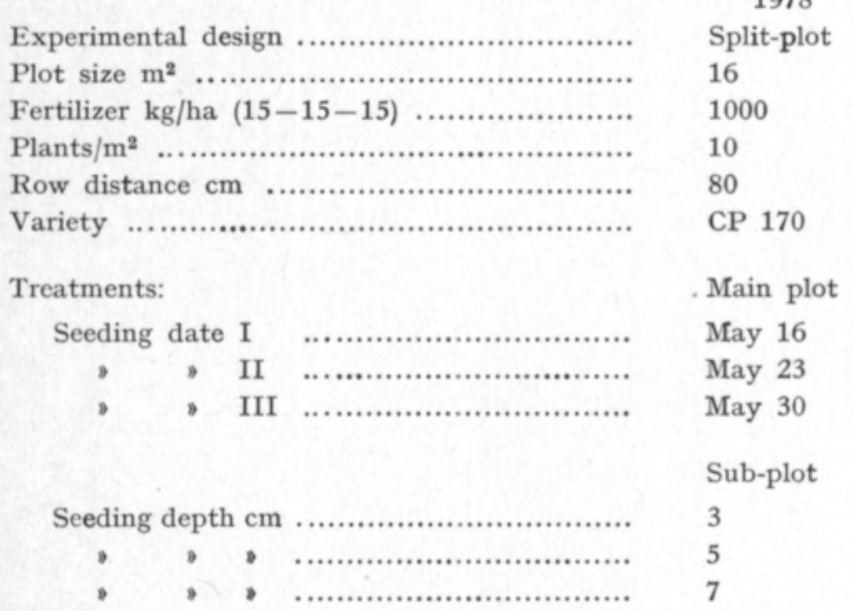

1978

Split-plot

16

80

May 16

May 23

May 30

Sub-plot

7

The dry matter determinations were made by using $2 \times 200 \mathrm{gr}$ samples and drying the samples overnight at $100^{\circ} \mathrm{C}$. The raw protein content of the research material was determined by using the Kjehldal method. The plant height measurements were made weekly during the entire growing season. Weather data represents the values obtained from Maasoja, Vihti.

\section{Weather conditionsion}

The temperature conditions of the growing seasons $1976-78$ were somewhat below the average conditions for $1931-60$. The mean temperature from May 1 to Sept. 27 was $12.0^{\circ} \mathrm{C}$ in $1976,11.9^{\circ} \mathrm{C}$ in 1977 and $12.1^{\circ} \mathrm{C}$ in $1978 \mathrm{com}$ pared to $13.0^{\circ} \mathrm{C}$ as the long term average in the period 1931-60. Especially the July temperature did not reach the level desirable for maize growth in any of the research years. The precipitation figures $231-285 \mathrm{~mm}$ in $1976-78$ remained somewhat below the average $298 \mathrm{~mm}$ for the period from May 1 to Sept. 27 in 1931-60. The stands were irrigated two times in 1976-77 and once in 1978. The degree days $\left(\Sigma\right.$ daily avg. $\left.{ }^{\circ} \mathrm{C}\right)$ and effective degree days ( $\Sigma$ daily avg. ${ }^{\circ} \mathrm{C}-10^{\circ} \mathrm{C}$ ) expressed as cumulative temperature curves are pres ented in Fig. 1. 
Table 1. Plant density at four seeding times and days from seeding to emergence, tasseling and silking and the degree days (DD) of the same growing periods in 1976-77 in Suitia.

\begin{tabular}{|c|c|c|c|c|c|c|c|c|c|}
\hline \multirow{2}{*}{\multicolumn{3}{|c|}{ Seeding time }} & \multicolumn{2}{|c|}{ Seeding-emergence } & \multicolumn{2}{|c|}{ Seeding-tasseling } & \multicolumn{2}{|c|}{ Seeding-silking } & \multirow{2}{*}{$\begin{array}{c}\text { Plants } \\
/ \mathrm{m}^{2}\end{array}$} \\
\hline & & & Days & $\mathrm{DD}$ & Days & DD & Days & DD & \\
\hline \multicolumn{10}{|c|}{1976} \\
\hline I & $14 / 5$ & ......... & 11 & 148 & 96 & 1291 & 107 & 1440 & 9.2 \\
\hline II & $21 / 5$ & ......... & 17 & 179 & 95 & 1280 & 102 & 1376 & 8.7 \\
\hline III & $2 / 6$ & ......... & 18 & 209 & 90 & 1242 & $\cdots$ & $\cdots$ & 9.1 \\
\hline \multirow[t]{2}{*}{ IV } & $8 / 6$ & ......... & 15 & 178 & 83 & 1175 & $\cdots$ & $\ldots$ & 7.8 \\
\hline & & Avg. & 15 & 179 & 91 & 1247 & 105 & 1408 & 8.7 \\
\hline \multicolumn{10}{|c|}{1977} \\
\hline I & $11 / 5$ & ......... & 22 & 202 & 99 & 1334 & 103 & 1375 & 8.7 \\
\hline & $20 / 5$ & .......... & 21 & 191 & 93 & 1265 & 95 & 1290 & 8.9 \\
\hline III & $27 / 5$ & .......... & 16 & 183 & -- & $\cdots$ & $\cdots$ & $\cdots$ & 8.9 \\
\hline \multirow[t]{2}{*}{ IV } & $3 / 6$ & .......... & 14 & 234 & -- & $\ldots$ & $\cdots$ & $\ldots$ & 8.8 \\
\hline & & Avg. & 18 & 203 & 96 & 1300 & 99 & 1333 & 8.8 \\
\hline \multicolumn{10}{|c|}{ Average years } \\
\hline I & $\ldots .$. & ............ & 17 & 175 & 98 & 1313 & 105 & 1408 & 9.0 \\
\hline II & ..... & ............ & 19 & 185 & 94 & 1273 & 99 & 1333 & 8.8 \\
\hline III & $\ldots .$. & ............ & 17 & 196 & $\cdots$ & $\cdots$ & $\cdots$ & $\cdots$ & 9.0 \\
\hline \multirow[t]{2}{*}{ IV } & $\ldots .$. & ........... & 15 & 206 & $\cdots$ & $\cdots$ & $\cdots$ & $\cdots$ & 8.3 \\
\hline & & Avg. & 17 & 191 & 96 & 1288 & 102 & 1371 & 8.8 \\
\hline
\end{tabular}

Table 2. Yields of three silage corn varieties at four different seeding times in Suitia, harvested Oct. 7. in 1976

\begin{tabular}{|c|c|c|c|c|}
\hline \multirow{2}{*}{ Seeding time } & \multirow{2}{*}{ Variety } & \multicolumn{3}{|c|}{ Yields tons/ha } \\
\hline & & Fresh & DM & Protein \\
\hline \multirow[t]{4}{*}{$14 / 5$} & Flash & $36.84^{\mathrm{a}}$ & $6.17^{\mathrm{a}}$ & $0.61^{\mathrm{ab}}$ \\
\hline & $L G 5$ & $34.88^{\mathrm{a}}$ & $5.54^{\mathrm{a}}$ & $0.59^{\mathrm{a}}$ \\
\hline & $A C G 200$ & $38.81^{\mathrm{a}}$ & $6.27^{\mathrm{a}}$ & $0.71^{\mathrm{b}}$ \\
\hline & Avg. & $36.84 \mathrm{~B}$ & $6.00 \mathrm{~B}$ & $0.64 \mathrm{~B}$ \\
\hline \multirow[t]{4}{*}{$21 / 5$} & Flash & $36.56^{\mathrm{a}}$ & $5.80^{\mathrm{a}}$ & $0.61^{\mathrm{a}}$ \\
\hline & $L G 5$ & $36.97^{\mathrm{a}}$ & $6.14^{\mathrm{a}}$ & $0.63^{\mathrm{a}}$ \\
\hline & $A C G 200$ & $39.56^{\mathrm{a}}$ & $5.69^{\mathrm{a}}$ & $0.64^{\mathrm{a}}$ \\
\hline & Avg. & $37.64 \mathrm{~B}$ & $5.87 \mathrm{~B}$ & $0.63 \mathrm{~B}$ \\
\hline \multirow[t]{4}{*}{$2 / 6$} & Flash & $25.79^{\mathrm{a}}$ & $3.98^{\mathrm{a}}$ & $0.42^{\mathrm{a}}$ \\
\hline & $L G 5$ & $28.47^{\mathrm{ab}}$ & $4.54 \mathrm{ab}$ & $0.54^{\mathrm{b}}$ \\
\hline & ACG 200 & $30.87^{\mathrm{b}}$ & $5.06^{\mathrm{b}}$ & $0.55^{b}$ \\
\hline & Avg. & $28.34 \mathrm{~A}$ & $4.52 \mathrm{~A}$ & $0.50 \mathrm{~A}$ \\
\hline \multirow[t]{4}{*}{$8 / 6$} & Flash & $27.03^{\mathrm{a}}$ & $4.25^{\mathrm{a}}$ & $0.49^{\mathrm{a}}$ \\
\hline & $L G 5$ & $28.04^{\mathrm{a}}$ & $4.39^{\mathrm{a}}$ & $0.54^{\mathrm{a}}$ \\
\hline & $A C G 200$ & $29.82^{\mathrm{a}}$ & $4.55^{\mathrm{a}}$ & $0.55^{\mathrm{a}}$ \\
\hline & Avg. & $28.30 \mathrm{~A}$ & $4.40 \mathrm{~A}$ & $0.53 \mathrm{~A}$ \\
\hline \multirow[t]{3}{*}{ LSD .05 } & Times & 6.0 & 0.70 & 0.08 \\
\hline & Varieties & 5.0 & NS & 0.05 \\
\hline & $\mathrm{T} \times \mathrm{V}$ & NS & NS & NS \\
\hline
\end{tabular}


Only the first two seeding dates could produce the silking stage of silage maize in 1976-77. The average growing day requirements for silking stages were 102 days. The second seeding speeded up development by six days over the first seeding. The temperature sum in degree days (Table 1) from seeding to silking of $1371^{\circ} \mathrm{C}$ conforms well with the variation level of 1232 to $1919^{\circ} \mathrm{C}$ presented by SEELEY (1917).

The seeding date did not affect plant population density (Table 1). This indicates good moisture conditions during the whole germination time.

Yields and forage quality

Seeding times I and II in 1976 produced equal yields of fresh weight, dry matter and protein. The yields were significantly higher than those of seeding times III and IV (Table 3). In 1977 the trend was similar to that of 1976.

Table 3. Yields of three silage corn varieties at four different times in Suitia, harvested Sept. 24. in 1977.

\begin{tabular}{|c|c|c|c|c|}
\hline \multirow{2}{*}{ Seeding time } & \multirow{2}{*}{ Variety } & \multicolumn{3}{|c|}{ Yields tons/ha } \\
\hline & & Fresh & DM & Protein \\
\hline \multirow[t]{4}{*}{$11 / 5$} & Flash & $37.1^{\mathrm{a}}$ & $5.92^{\mathrm{a}}$ & $0.85^{\mathrm{c}}$ \\
\hline & $L G 11$ & $43.3^{\mathrm{b}}$ & $6.80^{\mathrm{b}}$ & $0.60^{\mathrm{a}}$ \\
\hline & $H I T$ & $36.3^{\mathrm{a}}$ & $5.70^{\mathrm{a}}$ & $0.68^{b}$ \\
\hline & Avg. & $38.9 \mathrm{C}$ & $6.14 \mathrm{C}$ & $0.71 \mathrm{~B}$ \\
\hline \multirow[t]{4}{*}{$20 / 5$} & Flash & $37.3^{\mathrm{b}}$ & $5.72^{\mathrm{a}}$ & $0.66^{\mathrm{b}}$ \\
\hline & $L G 11$ & $41.8^{\mathrm{e}}$ & $6.68^{b}$ & $0.81^{\mathrm{e}}$ \\
\hline & $H I T$ & $33.0^{\mathrm{a}}$ & $5.33^{\mathrm{a}}$ & $0.57^{\mathrm{a}}$ \\
\hline & Avg. & $37.4 \mathrm{AB}$ & $5.91 \mathrm{BC}$ & $0.68 \mathrm{~B}$ \\
\hline \multirow[t]{4}{*}{$27 / 5$} & Flash & $32.3^{\mathrm{b}}$ & $5.04^{\mathrm{a}}$ & $0.55^{\mathrm{a}}$ \\
\hline & $L G 11$ & $38.1^{\mathrm{e}}$ & $5.74^{\mathrm{b}}$ & $0.63^{b}$ \\
\hline & $H I T$ & $30.7 \mathrm{a}$ & $4.51^{\mathrm{a}}$ & $0.51^{\mathrm{a}}$ \\
\hline & Avg. & $33.7 \mathrm{~B}$ & $5.10 \mathrm{~B}$ & $0.57 \mathrm{~A}$ \\
\hline \multirow[t]{4}{*}{$3 / 6$} & Flash & $28.1^{\mathrm{a}}$ & $4.06 \mathrm{ab}$ & $0.50^{\mathrm{a}}$ \\
\hline & $L G 11$ & $28.8^{\mathrm{a}}$ & $4.57^{\mathrm{b}}$ & $0.64^{b}$ \\
\hline & $H I T$ & $25.3^{\mathrm{a}}$ & $3.84^{\mathrm{a}}$ & $0.58^{\mathrm{b}}$ \\
\hline & Avg. & $27.4 \mathrm{~A}$ & $4.16 \mathrm{~A}$ & $0.57 \mathrm{~A}$ \\
\hline \multirow[t]{3}{*}{ LSD .05} & Times & 4.8 & 0.85 & 0.11 \\
\hline & Varieties & 2.0 & 0.31 & 0.04 \\
\hline & $\mathrm{T} \times \mathrm{V}$ & NS & NS & 0.08 \\
\hline
\end{tabular}

Although the early seedings suffered from relatively heavy frosts in both springs the seeding time between May 15 and May 25 can be recommended in our growing conditions.

Seeding time affected very little the quality of the forage maize under the growing conditions in 1976-77 (Table 4). The temperature sum in degree 
days only reached the level of $1700-1800^{\circ} \mathrm{C}$, which is far below the level required for significant changes in the dry matter and protein content of forage. Corrall et al. (1977) in Great Britain suggested that maize should require 2200 Ontario heat units ( $\mathrm{CHU}$ ) before drastic changes in the plant's water content can take place. This is possible only 2 to 3 times in ten years in Finland.

The late May and early June seedings resulted in shorter plant height (Table 4). The development in relation to the degree days is presented in Fig. 3. The plant heights of early and late seedings resembled each other. The growing seasons $1976-77$ were too unfavorable for any of the varieties studied to reach maturity.

Table 4. The average DM, protein and ear content (\%) and plant height (cm) of three silage varieties seeded at four different times in 1976-77.

\begin{tabular}{|c|c|c|c|c|c|c|}
\hline \multirow{2}{*}{\multicolumn{3}{|c|}{ Seeding time }} & \multicolumn{3}{|c|}{ Content $\%$} & \multirow{3}{*}{ Plant height $\mathrm{cm}$} \\
\hline & & & \multirow[t]{2}{*}{ DM } & \multirow{2}{*}{$\begin{array}{l}\text { Prot. } \\
1976\end{array}$} & \multirow[t]{2}{*}{ Ears } & \\
\hline & & & & & & \\
\hline I & $14 / 5$ & (n................ & $16.3^{\mathrm{a}}$ & $10.6^{\mathrm{s}}$ & $3.2^{\mathrm{b}}$ & $233^{b}$ \\
\hline II : & $21 / 5$ & (n................... & $15.6^{\mathrm{a}}$ & $10.7^{\mathrm{a}}$ & $1.5^{\mathrm{a}}$ & $225^{b}$ \\
\hline III & $2 / 6$ & (..................... & $15.8^{\mathrm{a}}$ & $11.1^{\mathrm{s}}$ & $\cdots$ & $204^{\mathrm{a}}$ \\
\hline \multirow{3}{*}{ IV } & $8 / 6$ & ................... & $15.6^{\mathrm{a}}$ & $11.9^{\mathrm{a}}$ & $\cdots$ & $202^{\mathrm{a}}$ \\
\hline & & Avg. & $15.8 \mathrm{~B}$ & $11.1 \mathrm{~A}$ & $2.4 \mathrm{~A}$ & $216 \mathrm{~A}$ \\
\hline & & & & 1977 & & \\
\hline I & $11 / 5$ & .................... & $15.8^{\mathrm{a}}$ & $12.8^{\mathrm{b}}$ & $5.1^{\mathrm{b}}$ & $221^{\circ}$ \\
\hline II 2 & $20 / 5$ & (n................ & $15.4^{\mathrm{a}}$ & $11.8^{\mathrm{a}}$ & $3.4^{\mathrm{a}}$ & $225^{\mathrm{c}}$ \\
\hline III 2 & $27 / 5$ & .................... & $15.1^{\mathrm{a}}$ & $11.1^{\mathrm{a}}$ & $\ldots$ & $203^{b}$ \\
\hline \multirow[t]{3}{*}{ IV } & $3 / 6$ & .................... & $15.1^{\mathrm{s}}$ & $13.8^{\mathrm{b}}$ & $\cdots$ & $190^{\mathrm{a}}$ \\
\hline & & Avg. & $15.4 \mathrm{~A}$ & $12.4 \mathrm{~B}$ & $4.3 \mathrm{~A}$ & $210 \mathrm{~A}$ \\
\hline & & & \multicolumn{3}{|c|}{ Average years } & \\
\hline I & ..... & …................ & $16.1^{\mathrm{a}}$ & $11.7^{\mathrm{ab}}$ & $4.2^{\mathrm{a}}$ & $227^{\circ}$ \\
\hline II & $\ldots .$. & ....................... & $15.5^{\mathrm{a}}$ & $11.3^{\mathrm{s}}$ & $2.5^{\mathrm{s}}$ & $225^{\circ}$ \\
\hline III & ..... & ...................... & $15.5^{\mathrm{a}}$ & $11.1^{\mathrm{a}}$ & $\ldots$ & $204^{b}$ \\
\hline \multirow[t]{2}{*}{ IV } & ..... & ...................... & $15.4^{\mathrm{a}}$ & $12.9^{\mathrm{b}}$ & $\cdots$ & $196^{\mathrm{a}}$ \\
\hline & & Avg. & 15.6 & 11.8 & -.. & 213 \\
\hline \multirow[t]{3}{*}{ LSD } & .05 & Years ........... & 0.3 & 0.8 & NS & NS \\
\hline & & Times .......... & NS & 1.1 & 0.9 & 8.0 \\
\hline & & $\mathrm{Y} \times \mathrm{T} \ldots \ldots$. & NS & NS & NS & NS \\
\hline
\end{tabular}

\section{B. Seeding densities 1976-77}

In the field trials in 1976-77 plant population densities of 7,10 and 13 plants $/ \mathrm{m}^{2}$ were tested to observe growth and development of the crop. During the research period the seeding rate did not affect the development of the maize crop (Table 5). Under growing conditions better than those of 1976-77 
Fig. 2. Relationship between daily average temperature and emergence time in days of maize in $1976-78$.
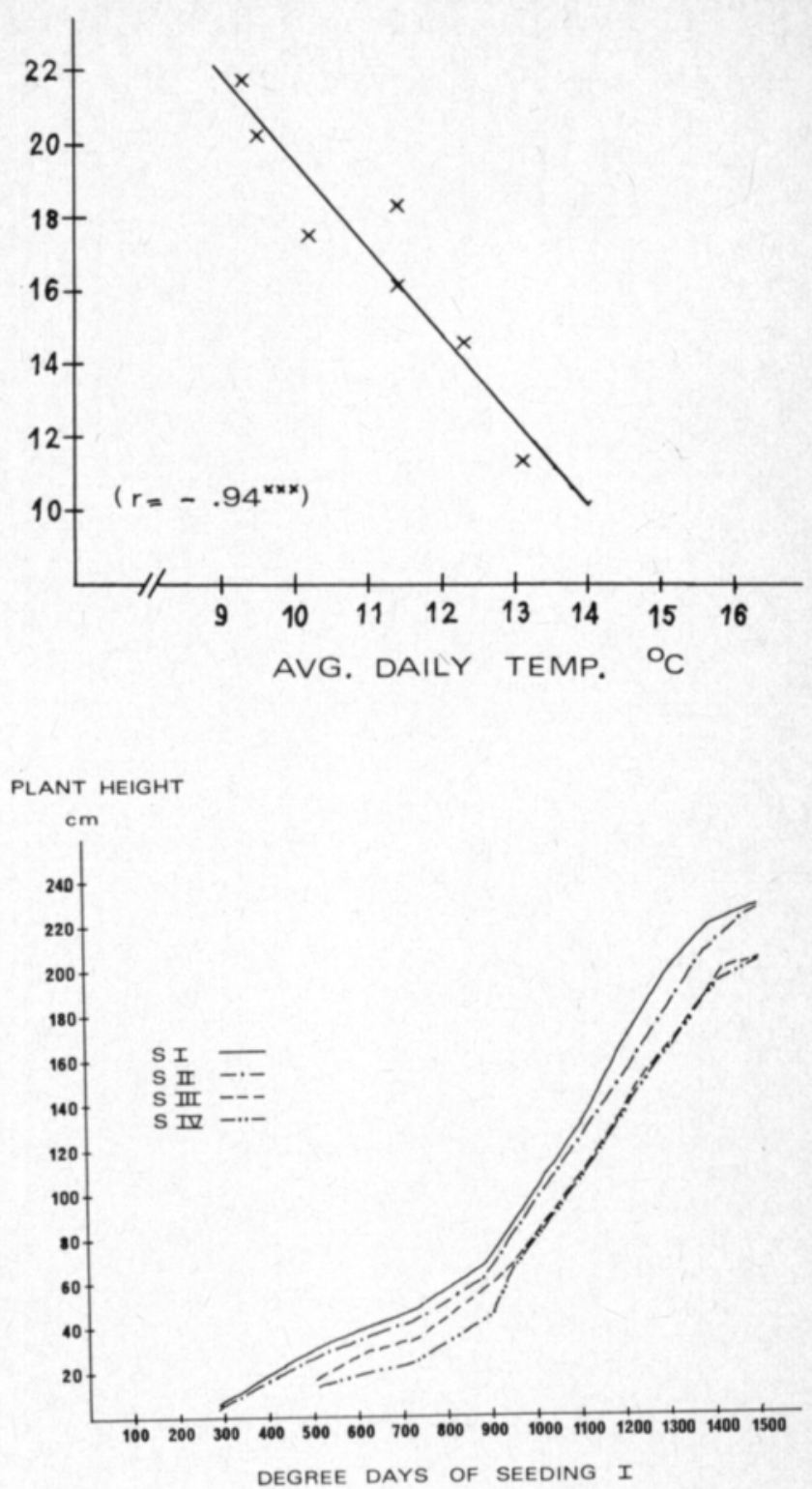

Table 5. Days from seeding to emergence, tasseling and silking of silage maize at three different seeding densities in 1976-77.

\begin{tabular}{|c|c|c|c|c|c|c|c|c|c|}
\hline \multirow{3}{*}{$\begin{array}{c}\text { Seeding } \\
\text { density } \\
\text { Plants/ha }\end{array}$} & \multicolumn{6}{|c|}{ Days from seeding } & & & \\
\hline & \multicolumn{3}{|c|}{ Emergence } & \multicolumn{3}{|c|}{ Tasseling } & \multicolumn{3}{|c|}{ Silking } \\
\hline & 1976 & 1977 & Avg. & 1976 & 1977 & Avg. & 1976 & 1977 & Avg. \\
\hline 70000 & 12 & 24 & 18 & 99 & 108 & 104 & 109 & 112 & 111 \\
\hline $100000 \quad \ldots \ldots \ldots \ldots \ldots . . . .$. & 12 & 24 & 18 & 101 & 108 & 105 & 109 & 112 & 111 \\
\hline $130000 \quad \ldots \ldots \ldots \ldots \ldots . . . . . . . .$. & 12 & 24 & 18 & 101 & 108 & 105 & 110 & 112 & 111 \\
\hline
\end{tabular}


Table 6. Fresh weight, dry matter (DM) and protein, yields of silage maize in 1976-77 at three different plant densities and the amount of ears (\%) in the yield.

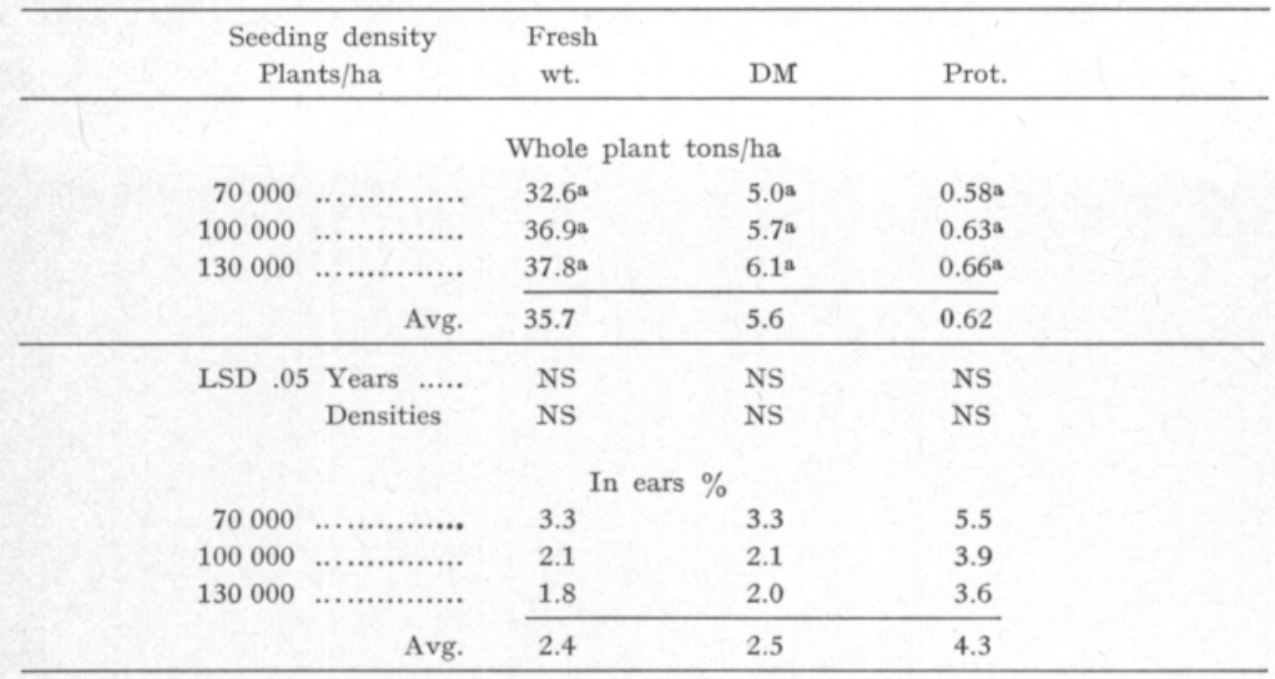

Table 7. Dry matter content (\%), the content of protein $(\%)$ and the plant height in the fall of silage maize in $1976-77$ at thrree different seeding densities.

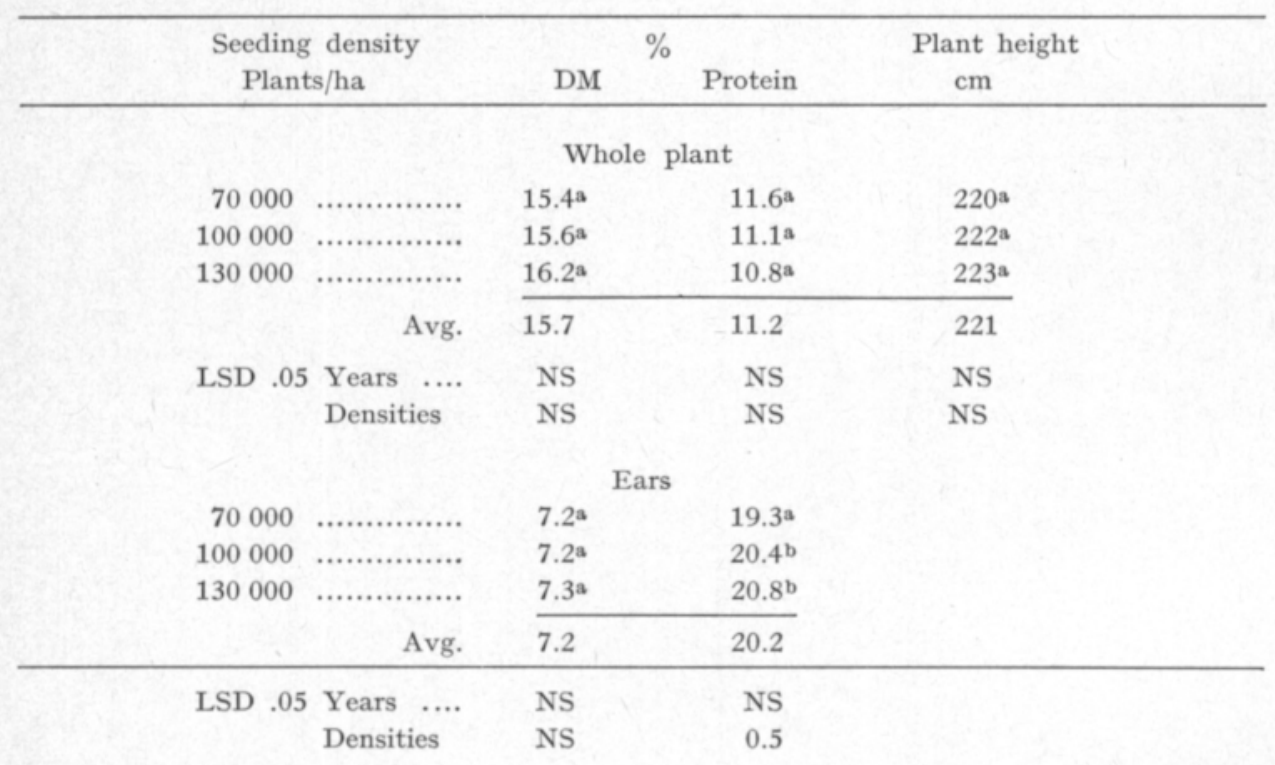

more developmental differences can be expected between sparce and dense populations. The test years did not produce any differences in dry matter and protein production between the stands of different densities (Table 6).

The population densities of $7-13 / \mathrm{m}^{2}$ tested in $1976-77$ present significantly thinner stands than those tested by Gelin and Gustafsson (1959) and ÅrerG and LARsson (1959) in Sweden and Yllö (1962) in Finland. The seeding densities of the open pollinated varieties in the 1950's represent levels of 25 to 35 plants $/ \mathrm{m}^{2}$. 
All the population densities in 1976-77 are characterized by the quality of the forage being inadequate for intensive animal feeding (Table 7). Under growing conditions beter than those of the test years one can expect with a thinner population density to harvest a lower but more mature yield than with a dense population of maize.

\section{Seeding dates and depths}

Because of the relatively late seeding date requirement and the very dry early summer in southern Finland the seeding depth is a very important management factor in the maize cultivation technique. In the management study for 1978 the minimum requirement for the seeding depth was $5 \mathrm{~cm}$ at all seeding times (Table 8). Deep seeding improved all quality characteristics of the crop. Deep seeding may delay the emergence date due to low temperature in the seed environment which should be at leat $+8^{\circ} \mathrm{C}$ for germination ( $\AA$ BERG and LARSSON 1959). The desirable daily mean temperature of the planting day should be at least $+12.8^{\circ} \mathrm{C}$ (Brown 1975). This requirement can be met mostly between May 15 and May 25 .

Table 8. The effect of seeding time and seeding depth on yield, quality and plant height of silage maize variety Cargill Primeur 170.

\begin{tabular}{|c|c|c|c|c|c|c|c|c|}
\hline \multirow{2}{*}{$\begin{array}{c}\text { Seeding } \\
\text { Date }\end{array}$} & \multirow{2}{*}{$\begin{array}{c}\text { Depth } \\
\mathrm{cm}\end{array}$} & \multicolumn{3}{|c|}{ Yields tons/ha } & \multicolumn{3}{|c|}{ Content \% } & \multirow{2}{*}{$\begin{array}{c}\text { Plant } \\
\text { height } \mathrm{cm}\end{array}$} \\
\hline & & Fresh & DM & Prot. & DM & Prot. & Ears & \\
\hline \multirow[t]{4}{*}{$16 / 5$} & $3 \mathrm{~cm}$ & $16.1^{\mathrm{a}}$ & $1.96^{\mathrm{a}}$ & $.25^{\mathrm{a}}$ & $12.4^{\mathrm{a}}$ & $12.5^{\mathrm{a}}$ & $7.9 \mathrm{ab}$ & $161^{\mathrm{a}}$ \\
\hline & $5 \mathrm{~cm}$ & $25.6^{\mathrm{b}}$ & $3.41^{\mathrm{b}}$ & $.37^{\mathrm{b}}$ & $13.4^{\mathrm{a}}$ & $10.8^{\mathrm{a}}$ & $5.1^{\mathrm{a}}$ & $170^{\mathrm{b}}$ \\
\hline & $7 \mathrm{~cm}$ & $24.8^{\mathrm{b}}$ & $3.32^{\mathrm{b}}$ & $.38^{\mathrm{b}}$ & $13.4^{\mathrm{a}}$ & $11.5^{\mathrm{a}}$ & $13.3^{\mathrm{b}}$ & $171^{b}$ \\
\hline & Avg. & $22.2 \mathrm{~A}$ & $2.90 \mathrm{~A}$ & $.33 \mathrm{~A}$ & $13.1 \mathrm{~A}$ & $11.6 \mathrm{~B}$ & $8.8 \mathrm{~B}$ & $167 \mathrm{~A}$ \\
\hline \multirow[t]{4}{*}{$23 / 5$} & $3 \mathrm{~cm}$ & $16.9^{\mathrm{a}}$ & $2.15^{\mathrm{a}}$ & $.27 \mathrm{a}$ & $12.7^{\mathrm{a}}$ & $12.3^{\mathrm{b}}$ & $4.2^{\mathrm{a}}$ & $151^{\mathrm{a}}$ \\
\hline & $5 \mathrm{~cm}$ & $24.2^{\mathrm{b}}$ & $3.14 \mathrm{ab}$ & $.32^{\mathrm{a}}$ & $13.0^{\mathrm{a}}$ & $10.2^{\mathrm{a}}$ & $6.7^{\mathrm{a}}$ & $168^{b}$ \\
\hline & $7 \mathrm{~cm}$ & $28.5^{\mathrm{b}}$ & $3.76^{\mathrm{b}}$ & $.37^{\mathrm{a}}$ & $13.0^{\mathrm{a}}$ & $9.7^{\mathrm{a}}$ & $6.1^{\mathrm{a}}$ & $170^{\mathrm{b}}$ \\
\hline & Avg. & $23.2 \mathrm{~A}$ & $3.02 \mathrm{~A}$ & $.32 \mathrm{~A}$ & $12.9 \mathrm{~A}$ & $10.7 \mathrm{~A}$ & $5.7 \mathrm{~A}$ & $163 \mathrm{~A}$ \\
\hline \multirow[t]{9}{*}{$30 / 5$} & $3 \mathrm{~cm}$ & $23.5^{\mathrm{a}}$ & $2.85^{\mathrm{a}}$ & $.38^{\mathrm{a}}$ & $11.8^{\mathrm{a}}$ & $13.4^{\mathrm{a}}$ & $3.2^{\mathrm{a}}$ & $160^{\mathrm{a}}$ \\
\hline & $5 \mathrm{~cm}$ & $34.8^{\mathrm{b}}$ & $4.29^{\mathrm{b}}$ & $.53^{\mathrm{b}}$ & $12.3^{\mathrm{ab}}$ & $12.3^{\mathrm{a}}$ & $1.9^{\mathrm{a}}$ & $174^{b}$ \\
\hline & $7 \mathrm{~cm}$ & $34.6^{b}$ & $4.55^{b}$ & $.51^{\mathrm{b}}$ & $13.2^{\mathrm{b}}$ & $11.1^{\mathrm{a}}$ & $2.9^{\mathrm{a}}$ & $180^{\mathrm{b}}$ \\
\hline & Avg. & $31.0 \mathrm{~B}$ & $3.90 \mathrm{~A}$ & $.47 \mathrm{~B}$ & $12.4 \mathrm{~A}$ & $12.3 \mathrm{~B}$ & $3.0 \mathrm{~A}$ & $171 \mathrm{~A}$ \\
\hline & \multicolumn{8}{|c|}{ Seeding depths, Avg. } \\
\hline & $3 \mathrm{~cm}$ & $18.8^{\mathrm{a}}$ & $2.32^{\mathrm{a}}$ & $.30^{\mathrm{a}}$ & $12.3^{\mathrm{a}}$ & $12.7^{\mathrm{b}}$ & $5.1^{\mathrm{a}}$ & $157^{a}$ \\
\hline & $5 \mathrm{~cm}$ & $28.2^{\mathrm{b}}$ & $3.61^{\mathrm{b}}$ & $.41^{\mathrm{b}}$ & $12.9^{\mathrm{ab}}$ & $11.1^{\mathrm{a}}$ & $4.6^{\mathrm{a}}$ & $171^{b}$ \\
\hline & $7 \mathrm{~cm}$ & $29.3^{\mathrm{b}}$ & $3.88^{\mathrm{b}}$ & $.42^{\mathrm{b}}$ & $13.2^{\mathrm{b}}$ & $10.8^{\mathrm{a}}$ & $7.4^{\mathrm{a}}$ & $174^{\mathrm{b}}$ \\
\hline & Avg. & 25.4 & 3.27 & .38 & 12.8 & 11.5 & 5.7 & 167 \\
\hline \multirow[t]{3}{*}{ LSD .05} & Times & 6.3 & NS & .12 & NS & .9 & 2.9 & NS \\
\hline & Depths & 4.2 & .61 & .07 & .7 & 1.5 & NS & 5 \\
\hline & $\mathrm{T} \times \mathrm{D}$ & NS & NS & NS & NS & NS & NS & NS \\
\hline
\end{tabular}




\section{Conclusions}

The following results can be drawn from the study:

1. Maize can be seeded between May 15 and May 25 without any great harm from cold period in the spring. New hybrids can tolerate temperatures as low as $-4^{\circ} \mathrm{C}$ to $-8^{\circ} \mathrm{C}$.

2. Seeding depths $5-8 \mathrm{~cm}$ are recommended for good germination and emergence.

3. Seeding densities of 10 plants $/ \mathrm{m}^{2}$ are adequate for high yield and good quality forage. Under better than average growing conditions a thinner population density can produce a more mature yield.

4. With conditions in which the temperature in degree days is less than $1900^{\circ}$ $\mathrm{C}$ the seeding date or variety have very little effect on a more rapid development of the stand.

\section{REFERENCES}

Anon. 1974. Farmers Weekly. Extra-Maize. Production. May 31. 1974.

Brown, D. 1975. Heat units for corn in Southern Ontario. Ministry of Agriculture and Food. Factsheet No 75-077. 4 p.

Bunting, E. \& Willey, E. 1957. The emergence of maize from field sowings in Great Britain.

1. The effect of date of sowing on the extent and speed of emergence of different varieties. J. Agric. Sci. 48: 447-56.

Corrall, A., Heard, A., Fenlon, J., Terry, C. \& Lewis, G. 1977. Whole crop foreages. Relationship between stage of growth, yield and forage quality in small-grain cereals and maize. Grassl. Res. Inst. Tech. Rep. 22. 35 p.

Gelın, O. \& Gustafsson, H. 1959. Odlingstekniska försök med fodermajs i södra Sverige. Växtodling 11: 10-25.

LARsSoN, R. 1959. Inverkan av utsädesmängd och radavstånd på utveckling och avkastning av ensilagemajs. Växtodling 11: 44-53.

Martin, J., Leonard, W. \& Stamp, D. 1975. Principles of field crop production. Indian corn. pp 323-382. Macmillan Pub. Co. New York.

Nösberger, J. 1971. Einflus der Bestandedichteauf die Ertragsbildung bei Mais. Z. Ackerund Pfl.bau 133: 215-232.

Ravantrı, S. 1960. Lisärehukasvit. Hankkijan Kasvinjalostuslaitos. Siemenjulkaisu 1960: $156-175$.

SEELEY, D. 1917. Relation between temperature and crops. Mon. Weath. Rev. 45: $354-9$.

Wallace, H. \& Bressman, E. 1937. Corn and corn growing. 431 p. John Wiley \& Sons, New York.

Virtanen, A. I. 1940. Maissin viljelyksestä ensi kesänä. Karjatalous 8. Erip. 7 p.

YLLö, L. 1962. Maissin viljelykokeista Suomessa. Maatal. ja Koetoim. 16: 101-110.

ÅBERG, E. \& LARsson, R. 1959. Odlingstekniska försök med ensilagemajs i mellersta Sverige. Växtodling 11: 26-43.

Ms received May 3, 1979. 


\section{Maissin viljelytekniikasta Suomen kasvuoloissa}

Seppo Pulli

Helsingin yliopisto, Kasvinviljelytieteen laitos, 00710 Helsinki 71

Osmo Kara

Helsingin yliopisto, Maatalousteknologian laitos, 00710 Helsinki 71

P. M. A. Tigerstedt

Helsingin yliopisto, Kasvinjalostustieteen laitos, 00710 Helsinki 71

G. BRÜninghaus,

Wiurila, 24910 Halikko

Yliopiston koetilalla Siuntiossa tutkittiin vuosina 1976-78 aikaisuudeltaan erilaisten lajikkeiden käyttäytymistä ilmastossamme ja sellaista viljelytekniikkaa, joka parhaiten takaisi maissin menestymisen kasvuoloissamme.

Yhteenvetona tutkimuksista todettakoon, että sääolot tutkimusajanjaksona olivat niin epäsuotuisat, että mistään eroista ei voida puhua, koska paraskin vaihtoehto sekä kasvutiheysettä kylvöaikakokeissa antoi epätyydyttävän lopputuloksen sekä määrän, että ennen kaikkea laadun suhteen. Tärkeimpänä syynä alhaiseen $6-7$ tn $\mathrm{kg} / \mathrm{ha}$ satotasoon olivat alkukesän kasvun keskeyttäneet alhaiset lämpötilat sekä kasvukausien lämpötilasummien epätyydyttävä kehittyminen.

Maissin kylvöajaksi suositellaan 15-25 toukokuuta. Suhteellisen alhaiset minimilämpötilat kesäkuun alkupuolella $\left(-4^{\circ} \mathrm{C}--6^{\circ} \mathrm{C}\right)$ vahingoittavat kasvustoja, mutta eivät tapa niitä. Seurauksena on pidentynyt kasvuaika. Aikaisesta kylvöstä saatua etua ei kuitenkaan kokonaan menetetä kevätpakkasissa.

Kylvö matalampaan kuin $5 \mathrm{~cm}$ tuottaa harventuneen, kuivuudelle alttiin kasvuston ja alentuneen satotason. Suurimpana turvallisena kylvösyvyytenä on pidettävä $8 \mathrm{~cm}$. Kasvutiheydellä $10 \mathrm{kpl} / \mathrm{m}^{2}$ saavutetaan maksimi satotaso kasvutekijöiltään normaalina kasvukautena Kasvutekijöiltään keskimääräistä suotuisampana kasvukautena saattaa alhaisempi kasvutiheys $6-8 \mathrm{kpl} / \mathrm{m}^{2}$ tuottaa kypsemmän ja laadultaan paremman sadon. 